\title{
The Teaching Research Methods in Management Course: Should We go beyond the survey?
}

Fernanda Roda de Souza Araújo

Cassundél Nildo Ferreira Cassundé Júnior ${ }^{l}$ Gislene Farias de Oliveira ${ }^{2}$

\begin{abstract}
The production of knowledge can happen not only through the transfer of knowledge, but it is also possible to produce it through the scientific research. Thinking about the teaching that enables analytical attitudes, reflexive, questioning and problem-solving, which learning comes from own observations to inquire about the knowledge and the world itself, implies articulate it with research and therefore related to the discipline of research methodology, core the discussion of this theoretical essay. Being the search the soul of academic life, it becomes a tool in the production of knowledge and important strategy to integrate knowledge, fragmented because of curricular and technicist disciplines programs structures, specialist teachers and fragmented teaching methodologies. Of the theoretical discussion we conclude that yes, we should go beyond the survey if we want to privilege a critical training, allowing students the opportunity how to learn to learn.
\end{abstract}

Keywords: teaching and research in administration, scientific methodology, survey.

\section{Introduction}

The University is, of excellence, a knowledge production space. Knowledge is not only transmitted but produced by scientific research. In this sense, Barbosa et al (2013) understand that there is no single way to produce knowledge; there is no single explanation for a social phenomenon; there is no single way of interpreting data, as well as there is no single and unquestionable truth. Japiassu (1991) corroborates the question scientific thought which is based on definitive truths and leads us to reflect on the processual character of knowledge, recognizing it, not as a state, but always temporary, always a becoming.

This implies that the positivist paradigm, whose beginning goes back to middle of the XIX century, with August Comte, with the idea that knowing only means to measure and quantify, appears to be surmounted by a non-linear approach, as "a simplistic view of how the world works is being replaced by an essentially complex and paradoxical "(Parker \& Stacey 1995 p. 12).

\footnotetext{
${ }^{1}$ Federal 1 University of Vale do São Francisco, Pernambuco, Brazil. E-mail: fernanda.roda@univasf.edu.br; nildo.cassunde@univasf.edu.br; ${ }^{2}$ Federal University of Cariri, Ceará, Brazil.E-mail: gislenefarias@ gmail.com.
} 
Thus, the conventional models of management guidance and decision making processes, argue Borinelli, Lacerda and Rampazo (2007), seems to be more appropriate, since "it has become commonplace speak in turbulence and instability of the environment and market . Within companies, the decision-making at all levels has become increasingly risky and uncertain "(Bauer, 1999, p.9).

This scenario places a challenge for business schools. According to War (2001), it is not management undergraduate course more expected the formation of trained professionals with a view only to the solution of problems, is expected to more than one professional in a changing world. Rather than training him to give ready answers to routine problems, we should educate you to greater challenges. Therefore, it becomes important that the Management undergraduate courses in this new context, privilege "not only the necessary technical and not even transfer to their students only ready formulas, but they are also concerned about bringing the critical side, giving students the opportunity to learn for learn, "he adds Spers (2001, p. 15).

Thinking about the teaching that enables analytical attitudes, reflective, questioning and problem-solving, whose learning of the own observations to inquire about the knowledge and the world itself, implies articulates it with research suggests Almeida et al (2002).

In this sense, research, understood as forming process becomes a constituent and essential element of the process of learning for learn, evaluates Pereira (2001), and therefore must prevail in various curricular times, especially in higher education.

In this context, the critical student education and its continuous learning brings out the teaching of research methods in management which, purely academic nature, "the research is seen as strategic in training managers" (Borinelli, Lacerda \& Rampazo, 2007, p.2).

Faced with the basilar tripod teaching-research-extension, in which universities are anchored, the practice of research in Administration courses, especially during graduation, is directly related to research methodology discipline evaluates Fehlaber et al (1992). This is the time, therefore, to be awakened the importance of the need to research, because "it is common observation that the scientific method is one of the strategic issues in academic education, especially towards the motivation for research," adds Demo (2006, p.24).

That said, we have the problematic focus of this article, namely, the methodology teaching of research in management courses. It is hoped that this theoretical essay clarify 
issues relevant to teaching barriers such discipline and their involvement with interdisciplinary aspects, as well as situate the survey research in Management course content.

\section{About Teaching Research Methods}

"Top-level studies will force us to consume an ever increasing amount of fruits of research, and increasingly advanced research," say Laville and Dione (1999, p.275).

In this sense, "the study of research methods gives the student the knowledge and skills to solve problems and overcome challenges of a decision-making environment that moves at a fast pace" (Cooper \& Schindler 2003, p.26); therefore, it is expected according to Araujo (2004), the new business administration are, both locally and globally focused, that is, inserted in a context of globalization, in which there is a growing need for better and better information to assist in the decision-making process.

Thus, to do well in this environment, we will need this new professional understand "how to identify quality information to recognize a solid and reliable research in which its high-risk decisions, as administrator, can be based," adds Cooper and Schindler (2003, p.27), ie the research should be seen as a normal way to face the real-world problems (Mayoral \& Tesoro, 2005).

It is equally important that this new professional to be able to "use search as a permanent process of renewal their competence" (Demo 2000, p.161). Thus, from the point of view of modern professional, Demo (1996) says that it is necessary to to be interested in constantly for knowledge on the profession, following the news through the search for information, selective reading and systematic, and the research currently an of the main tools available for acquiring knowledge.

In this sense, the discipline of Research Methods seems to have fundamental role in the development of scientific studies in Management, whether made for Academy or markets, as the main support (perhaps only) in which many professionals rely on individual investigations, since "the discipline aims to instrumentalization for individual study, research, and particularly the disciplining of analytical thinking" (Fehlaber et al, 1992, p.1).

However, despite its recognized importance, the teaching of research methods as a discipline seems that developed five obstacles, namely: The first obstacle was the stance adopted on the subject by students. Bertero (1984) suggests that the graduate student would 
adopt a more viewer posture, worried, according Fehlaber et al (1992), essentially with the minimum score to get approved in the discipline; already graduate adopt a user posture, more concerned and conditioned by the pressure of having to write a paper for the degree.

To Fehlaber et al $(1992$, p.2) The second obstacle concerns the students of evening classes of Management, since it would be "counterproductive require students committed to professional activities, dedication to a search because they do not have to perform fieldwork ". Lima and Olivo (2007, p.13) add that, the student's early entry into the labor market corresponds to factors that contribute to strengthen the fragmented, superficial training content, reducing the course of disciplines whose approach does not exceed disjointed introductory notions, insufficient to develop skills. In such circumstances, the student does not study, or does not perform activities that promote effective learning processes.

Another potential problem related to educational research in Management methodology, setting the third obstacle is the frequent training methodology of teaching in social science (Bertero, 1984). As the teacher is "primary responsibility for stimulating the moment of creation" (Mattos, 2004 p.IX), "the lack of knowledge of the administrative area content causes inevitable distancing with respect to students and can direct the course for a type of exercise a little abstract and distanced "not motivating studentsto the practice of research, suggests Bertero (1984, p.139);

The fourth obstacle, argues Martins (1996, p.5), concerns to the degree to which the subject is taught. "Or 'rises' the level discussing Theory of Knowledge, or seeks to instrumentalize the student with research techniques," which usually do not go beyond the survey strategy;

In this sense, Lima $(2004$, p.4) argues that several training areas, including the Management, "are far from adopting an idealistic qualitative approach to the investigations carried out," most works, only the quantitative aspect (of data collection ). That's because much of the available literature on research methodology recognizes only the intrinsic processes the quantitative nature of methods as a condition sine qua non of scientific for investigation of phenomena, says Lima (2004), which only makes out the survey method as , "the best example for teaching methodology in the social sciences" (Babbie, 1999, p.82);

Despite the research methods teaching at management involve interdisciplinary aspects, this course is usually second Bertero (1984, p.139), "placed in the early part of the programs, even before they enter into substantive matters of compulsory center or several 
areas of concentration ", this sets the fifth obstacle of this discipline. Thus, students to attend research methodology does not have the knowledge of the various disciplines, making it difficult, exceedingly, conducting research, and in this sense, the practice of most common survey, because it ends up make it easier method, since you do not need, at first, of both reflective exercise (Bertero, 1984; Fehlaber et al, 1992).

It is important to say at this point that, still, when some kind of scientific work is done, what is verified is "a compilation of texts fragments understood not always [...], and therefore disjointed and unhelpful to the process of learning and (trans) formation of the student, "added Lima and Olivo (2007, p.15). In this sense, Lima (2004, p.3) points out that "it is contradictory and problematic that require students own academic production," because "the student completes the course without realizing a subject [...], does not commands, handles, constructs and interprets data "(Demo 2006, p.67). Thus, with regard to the product of the research ( survey), Freitas Oliveira, Saccol and Moscarola (2000, p.15) they say,

should be complete distinction between the fact of having become a mass data and the necessity of communicate verbally or in writing the results which have been reached. This is an activity that requires concentration and many other skills with which there should be concern.

What actually happens is that, because of the simplistic research training that they receive, many students remodel the research problem so that it fits into a specific methodology, as the survey, for example, highlight Cooper and Schindler (2003).

\section{The research methods teaching: interdisciplinary aspects}

The interdisciplinary concern is configured as the great paradigm for the educational issues. Although not a concern so recent, the issue of interdisciplinarity continues to be discussed and may be evidenced in the pedagogical projects of Higher Education Institutions (HEIs). "It is a requirement that is imposed to contemporary thought in all sciences, whether physical, natural or human" stands Dencker (2002, p.73). However, HEIs remain with the curricular structures and technologic subjects programs, specialist professors and teaching methodologies fragmented because there is no culture, such institutionalized point, to provide conditions for the development of interdisciplinary projects (Petraglia, 1991). On the other hand, the extent to which interdisciplinary studies gain space in the academic community, a 
new proposal to overcome the boundaries of disciplines and develop research through critical reflection is developed (Dencker 2002).

Interdisciplinarity is presented because, according Japiassú (1976, p.43), in the form of protest "against a knowledge fragmented into crumbs, powdered in a growing variety of specialties, each of which closes as if to escape the real knowledge". In this sense, a scientific research project for undergraduate students in Management, whose main purpose is complete in an organized and systematic training and preparation of university student, this fragmented formation during its passage through the university. The research thus appears as an integrative strategy of knowledge, since it proposes a "reflection on the epistemological division of knowledge into compartmentalized disciplines" (Japiassu 1976, p.50, emphasis added). Fazenda (1996, p.45) complements this idea emphasizing that "the meaning of of the investigations [research] interdisciplinary is to rebuild the unity of the object, that the fragmentation of the methods separated."

The issue of interdisciplinarity, therefore, appears to be related to the practice of scientific research, as suggested by Bertero (1984). To Fazenda (2001, p.18), which makes characterize an interdisciplinary approach in university is the "pursuit of daring, of the research." In this sense, Japiassú (1976, p.51, emphasis added) adds that "interdisciplinarity claims the characteristics of a scientific category, relating to research." "The soul of academic life is made up of the research as a strategy of knowledge generation" (Demo 1993, p.127, emphasis in original).

Therefore, for the interdisciplinary research practices were widespread in the academies, it is mister a change in the academic and university life as it is now essential to create spaces for the dissemination of scientific research and advanced research (Jantsch; Biachetti, 1995). Pereira (2001, p.12) points out that "the scientific initiation activity may induce the university administration to seek the path of autonomy, based on the existing knowledge to try to reach a more elaborate one, critically built. " Thus "the scientifically planned action will be so much better the more it is based on the results of an interdisciplinary research and not on a data juxtaposition derived from various disciplines" (Japiassu 1976, p.88, Griffin author). Learn, therefore, with the interdisciplinary that a fact or solution is not isolated, but rather a consequence of the relationship between many others.

The interdisciplinary research, therefore, they are creators and raise new ideas that experts could not figure out if they remained isolated and did not converge their views, their methods, 
their results, their epistemology, etc. Consequently, they inevitably have to face some resistance and opposition, both from experts and by the educational institutions, which hold back their development or that only make use of it in that it does not call into question the old epistemological division of knowledge (Japiassu 1976, p.99).

\section{And what we can talk about survey research?}

\section{Brief historical report of the development of survey research}

Due to the great similarities with other survey research methods, and in particular to the census, it is possible to say, according to Babbie (1999), its origin dates back at least to many years ago.

While the first census that has news is related to the ancient Egyptian civilization, whose "thought leaders reap useful empirical data describing his subjects" (Babbie, 1999, p.78), the survey research to political uses, in turn, dating back to 1880 . At this time Karl Marx sent about 25,000 questionnaires mailed to French workers to identify the degree to which were exploited by their employers; however, there is no record that he has received a questionnaire back. It is also known that Marx Weber "used in survey research methods in the study of the Protestant ethic" (Babbie, 1999, p.78).

The Americans however are the most responsible for the development of survey research, whose expansion is closely related to the three different sectors of American society, says Babbie (1999). For this author, the first to contribute, during the twentieth century was the US Bureau of Census, with important contributions to the field sampling and data collection. Despite being more recognized by the decennial census of the US population, the vast majority of its activities are connected with "a continuous series of previous surveys" (Babbie, 1999, p.78).

The companies specialized on opinion surveys, especially in the areas of product marketing and policy research (Gallup, for example), make up the second group that contributed to the expansion of the survey.

In times when there were no funds to support academic research survey, these commercial companies did experiment with sampling methods, essay of questions, data collection techniques and other survey research aspects (Babbie, 1999, p.79). 
Finally, the last sector to contribute to the "refinement of survey research, particularly sophisticated methods of analysis," according to Babbie (1999, p.79), were a few American universities, especially through the work of Samuel A. Stouffer and Paul F. Lazarsfeld, "considered the survey research pioneers as it is known today," said Babbie (1999, p.79). In addition, Paul Lazarsfeld helped create the Bureau for Applied Social Research at Columbia University (New York). Cooper and Schindler (2003, p.268) also add that currently "one of the leading research organizations in the world is the Survey Research Center at the Michigan University." This survey research center started its activities around the year 40s and since then has emerged as a leader, nationally and internationally, in interdisciplinary social research involving data collection or analysis of surveys of samples (SCR, 2007).

\section{The survey as a research method}

The frequency with which this method works in the discipline of management research methodology can be justified, according to Lima $(2004$, p.27) due to the fact that the "use of the survey method can be exemplified in view of the existence of significant regularly on the steps that characterize the investigative process".

The method of survey research is currently the one that best represents the characteristics of quantitative research, and that it corresponds to an approach of the phenomenon investigated involving the realization of a field research in which data collection is done by applying questionnaire and / or form with the target population of the research (Lima, 2004, p.26, emphasis added).

To Pinsonneault and Kramer (1993), there is an important distinction between survey and survey research.

The survey can be defined with a systematic method of collecting information from a group of people selected through a series of questions (Houston, 2006). It can also be described "as obtaining data or information about characteristics, actions or opinions of a certain group of people, appointed as a representative of the target population through a survey instrument, usually a questionnaire" as Freitas Oliveira, Saccol and Moscarola (2000, p.3). As a result, there are many databases and process measures that are called survey opinion surveys and voting intention survey are the most common (Pinsonneault \& Kramer, 
1993). The survey of research, however, to Pinsonneault and Kramer (1993, p.3) are driven by the advanced scientific knowledge.

The surveys conducted for research purposes have three distinct character according to Pinsonneault and Kramer (1993), namely:

- the purpose of the survey is to produce quantitative descriptions of some aspect of the study population. The analyzes, initially, may be related to the relationship between the variables or projection found for a pre-defined population (Glock, 1967 apud Pinsonneault \& Kramer, 1993);

- the main form of data collection is through the application of structured questions and pre-defined to the study population. The answers to the questions, which should refer to the study participants or other unit of analysis are the data to be analyzed;

- data are usually listed in only one part of the study population (sample), however, the strategy is made such that allows generalization of the population findings. Typically, the sample is representative enough to allow the extensive statistical analysis.

The quality of the sample survey, however, is assigned according Dillman (1978) and Fowler (1984) (cited Pinsonneault \& Kramer, 1993), to three key elements: research design, sampling procedures and methods data collection. Fowler Jr. (1988 apud Paiva, 1999, p.189) considers that the strength of the survey methods are related to the "value of statistical sampling used, the consistent action, and the ability to get information not available in any other location or in the form needed to be analyzed ".

Pinsonneault and Kraemer (1993) and Lima (2004) classifies the survey research through the purpose:

- explanatory when the research aims to test a theory and causal relationships;

- exploratory proposes to familiarize the researcher on the subject, or even identify initial concepts. Emphasizes the establishment of which concepts should be measured and how they should be measured, search also discover new possibilities and dimensions of the population of interest;

- descriptive, "when the investigation is committed to identify which situations, events, attitudes or opinions are manifest in a given population, or describe the distribution of some phenomenon occurred with the population", or a part, says Lima (2004, p. 27). 
Sampieri (apud Freitas; Oliveira; Saccol \& Moscarola, 2000) and Lima (2004) classify the sample survey on the number of moments:

- longitudinal data collection happens over time (in periods or specified points), committing itself to investigate the evolution, transformations or changes of certain variable;

- Cross-cutting, data collection happens in a moment, when you want to identify or explain one or more variables in a given time.

Although the "survey research on management area is quite usual" as Scornavacca Jr., Becker and Andraschko (2001, p.2), the survey does not end in itself, that is, for improving the quality of survey research, researchers should pay attention to the use of more than one method for collecting data, thus allowing the triangulation of information (Freitas; Oliveira; Saccol \& Moscarola, 2000).

\section{In conclusion}

This article aimed to discuss the teaching of scientific methodology in management discipline in undergraduate courses.

What can be concluded from the reflections proposed, and corroborating Borinelli, Lacerda and Rampazo (2007), it is that the conditions for teaching methods as a discipline in management undergraduate courses are unfavorable. The students are not sufficiently prepared for the practice of scientific research, since prevails technicalities and fragmented teaching in disciplines and consequently little interdisciplinary practice.

The organizations, in turn, are demanding managers capable of to manage prosperity and crisis with open view to the understanding of contemporary phenomena. The organizational models and the management of the work, based on the principles of Scientific Management, whose foundations date back to the Industrial Revolution, already no longer meet the demands of society and the market. The solutions are more complex, they need to research, new inspiration and diverse training for professionals. Their basic training requires articulation of knowledge of the various in disciplines inserted in the course curriculum. Thus, overcoming the barriers between disciplines that generate the fragmentation of knowledge, would be a possibility of understanding the unity of problems and to critically read the information available. 
It is therefore to undergraduate courses in management to pull away from the old traditional Cartesian approach, under whose inspiration the Board of Education has been divided since its first regulations in 1966. The fragmented education needs to be replaced by a more global vision of reality. We must begin to question the ineffectiveness of making the student solely responsible for the integration of fragmented content in various disciplines.

Interdisciplinary research arises as a possibility to overcoming the dichotomies, including one that distance teaching and research, a further step towards interdisciplinary curriculum. Anyway, would not be gathering the knowledge, in the form of disciplines, but bringing together the activities of teachers, the practice of cooperative work together around the same collective research problem, which integrated and interdisciplinary knowledge would be produced.

The interdisciplinary approach is therefore a stimulus for the discussion of reality, thus emphasizes the reconstruction, remake, a rethinking of the linear knowledge and the practice of research, a possible strategy to help the reflection on this epistemological division of knowledge into disciplines compartmentalized, to solve the problem of fragmentation of teaching in undergraduate courses in Management and training of the young professionals.

This implies an affirmative answer. Yes, we must go beyond the survey if we would focus a critical training, allowing students the opportunity to learn for learn.

\section{References}

Almeida, A. et al. (2002). O currículo como expressão do projeto pedagógico: um processo flexível (2000). In: Rodrigues, Mara Eliane Fonseca (org.). Fórum de pró-reitores de graduação das universidades brasileiras: resgatando espaços e construindo idéias: de 1997 a 2002. Niterói.

Araújo, Fernanda Roda de Souza. (2004). A pesquisa interdisciplinar na graduação em Administração: um estudo sobre condições para sua prática nas IES de Pernambuco. 2004. Dissertação (Mestrado) - Programa de Pós-Graduação em Administração (PROPAD), Universidade Federal de Pernambuco, Recife.

Babbie, Earl. (1999). Métodos de pesquisas de survey. Belo Holizonte: UFMG.

Barbosa, M. A. C. et al. (2013). "Positivismos" versus "interpretativismos": o que a Administração tem a ganhar com esta disputa? Organizações em contexto, 9(17), 1-29, jan./jun. 
Bauer, Ruben. (1999). Gestão da mudança: caos e complexidade nas organizações. São Paulo: Atlas, 1999.

Bertero, Carlos Osmar. (2006). Ensino e pesquisa em Administração. São Paulo: Thomson Learning.

Out./Dez.

(1984). O ensino de metodologia de pesquisa em administração. $R A E, 24(4)$,

Borinelli, Benilson; Lacerda, Paulo Eduardo; Rampazo, Adriana Vinholi. (2007). O ensino de pesquisa científica em cursos de graduação em administração: algumas lições da experiência da Universidade Estadual de Londrina. In: Encontro de Ensino e Pesquisa em Administração e Contabilidade, Recife. Anais... Recife: Anapd.

Cooper, Donald R.; Schindler, Pámela S. (2003). Métodos de Pesquisa em Administração. 7.ed. Porto Alegre: Bookman.

Demo, Pedro. (1993). Desafios modernos da educação. (2. ed.). Petrópolis, RJ: Vozes. . (2000). Metodologia de Conhecimento Científico. São Paulo: Atlas. .(1996). Metodologia em ciências sociais. São Paulo: Atlas. . (2006). Pesquisa: princípio científico e educativo. (12.ed.) São Paulo: Cortez.

Dencker, Ada de Freitas Maneti. (2002). Pesquisa e Interdisciplinaridade no Ensino Superior: Uma experiência no Curso de Turismo. São Paulo: Aleph.

Fazenda, Ivani C. Arantes. (1996). Integração e Interdisciplinariedade no ensino brasileiro: efetividade ou ideologia? (4. ed.). São Paulo: Loyola.

. (2001). Interdisciplinaridade: definição, projeto, pesquisa. In: FAZENDA, Ivani C. Arantes (org). Práticas interdisciplinares na escola. (8. ed.) São Paulo: Cortez.

Fehlaber, Adalbert Ruprecht Ribeiro. (1992). Pesquisa e exercício de pesquisa. In: III Encontro Anual da Associação Nacional dos Cursos de Graduação em Administração, 1992, Belo Horizonte. Anais... Belo Horizonte: Angrad.

Freitas, Henrique; Oliveira, Mirian; Saccol, Amarolinda Zanela \& Moscarola, Jean. (2000). O método de pesquisa survey. Revista de Administração da USP - RAUSP. São Paulo, 35(3), Jul./Set.

Guerra, Elaine Linhares de Assis. (2001). O ensino superior de Administração no Brasil: desafios do novo milênio. In: XII ENANGRAD, São Paulo, 2001. Anais... São Paulo: Angrad. 
HOUSTON, Archester. Survey Handbook. 2006. Disponível em: < http://unpan1.un.org/intradoc/groups/public/documents/aspa/unpan002507.pdf >. Acesso em: 01/08/2016.

Jantsch, Ari Paulo; Bianchetti, Lucídio. (1995). Universidade e Interdisciplinaridade. In: Jantsch, Ari Paulo; Bianchetti, Lucídio (orgs). Interdisciplinaridade: para além da filosofia do sujeito. (3. ed.). Petrópolis, RJ: Vozes.

Japiassu, H. (1991). As paixões da ciência. São Paulo: Letras \& Letras. (1996). Interdisciplinaridade e patologia do saber. Rio de Janeiro: Imago.

Laville, Christian \& Dionne, Jean. (1999). A construção do saber: manual de metodologia da pesquisa em ciências humanas. Porto Alegre: Artmed.

Lima, Manolita Correia. (2004). Monografia: a engenharia da produção acadêmica. São Paulo: Saraiva.

Lima, Manolita Correia \& Olivo, Silvio. (2007). Estágio Supervisionado e Trabalho de Conclusão de Curso: na construção da competência gerencial do administrador. São Paulo: Thomson Learning.

Mattos, Pedro Lincoln Carneiro Leão de. Prefácio. (2004). In: Lima, Manolita Correia. Monografia: a engenharia da produção acadêmica. São Paulo: Saraiva.

Martins, Gilberto de Andrade. (1996). Epistemologia da pesquisa em administração. In: XXXI Asamblea Anual CLADEA, 1996, Santiago. Anais... Santiago: CLADEA.

Mayoral, Luisa; Tesoro, José Luiz. (2005). Administración de empresas y metodología de investigación: aportes para un dialogo y una enseñanza efectivos. Read,.11(2), Mar./Abr.

Paiva, Ely Laureano. (1999). Conhecimento organizacional e o processo de formulação de estratégia de produção. 1999. Tese (Doutorado) - Programa de Pós-Graduação em Administração, Universidade Federal do Rio Grande do Sul, Porto Alegre.

Parker, David; Stacey, Ralph. (1995). Caos, administração e economia: as implicações do pensamento não linear. Rio de Janeiro: Instituto Liberal.

Pereira, Francisco Isidro. (2001). Ensino de graduação em Administração: entraves, desafios e perspectivas. Revista ANGRAD, 2(2), 3-14.

Petraglia, Izabel Cristina. (1991). O cultivo do professor: uma experiência interdisciplinar. 1991. Dissertação (Mestrado) - Programa de Pós-Graduação em Educação: Supervisão e Currículo, Pontifícia Universidade Católica de São Paulo, São Paulo.

Pinsonneault, A.; Kraemer, K. L. (1993). Survey research methodology in management information systems: an assessment. Journal of Management Information Systems, 10(2), Autumn. 
SCR. Survey Research $2007 . \quad$ Denter. Disponível em: <http://www.isr.umich.edu/src/index.html>. Acesso em: 01/08/2016.

SPERS, Valéria Rueda Elias. (2001). A educação e o contexto atual. In: In: SPERS, Valéria Rueda Elias; Siqueira, Elisabete Stradiotto \& Pizzinatto, Nadia Kassouf [et al.] (orgs.). Administração: Evolução, Desafios, Tendências. São Paulo: Cobra.

Received: $12 / 09 / 2016$.

Accepted: 14/10/2016

\section{How to cite this article (APA format):}

Cassundé, Fernanda R.S.A., Cassundé Júnior, Nildo F. \& Oliveira, Gislene F. (2016). The Teaching Research Methods in Management Course: Should We go beyond the survey? Am Int Mul J, 1(1), 59-72. 